\title{
Świadczenie pieniężne przysługujące policjantowi przywróconemu do służby w Policji za okres pozostawania poza służbą - wybrane zagadnienia
}

\author{
Cash benefit due to Police officer reinstated to the Police service \\ for a period of being out of service - selected issues \\ на службе в полиции за период перерыва в службе - избранные вопросы \\ PAWEŁ GACEK \\ Dr, Komenda Główna Policji \\ e-mail: p.gacek@wp.pl, https://orcid.org/0000-0001-6365-3146
}

Денежное довольствие, причитающееся сотруднику полиции, восстановленному

\begin{abstract}
Streszczenie: Artykuł w całości został poświęcony instytucji świadczenia pieniężnego przyznawanego w związku z przywróceniem policjanta do służby w Policji, która zawarta jest w art. 42 ust. 5 ustawy z dnia 6 kwietnia 1990 r. o Policji. Przywrócenie do służby następuje z mocy prawa z chwilą zmaterializowania się przesłanek określonych w art. 42 ust. 1 lub ust. 7 ustawy o Policji. Konsekwencją przywrócenia do służby jest obowiązek przyznania policjantowi świadczenia pieniężnego za okres pozostawania poza służbą. Jego przyznanie jest obligatoryjne, natomiast jego wysokość określa organ administracyjny. Przepis art. 42 ust. 5 ustawy o Policji określa minimalną i maksymalną wysokość tego świadczenia. Dokonano również omówienia charakteru prawnego tej instytucji oraz podmiotów uprawnionych do jej stosowania.
\end{abstract}

Słowa kluczowe: Policja, policjant, stosunek służbowy, przywrócenie do służby, zwolnienie ze służby, świadczenie pieniężne

Summary: The article has been entirely devoted to issues related to the institution of cash benefit which is granted in connection with the reinstatement to service in the Police, which is included in the Art. 42 (5) Act on the Police. Restoration to service occurs by virtue of law upon the materialisation of the conditions referred to in Art. 42 (1) or (7) Act on the Police. The consequence of reinstatement to service in the Police is the obligation to grant the Police officer cash benefit for the period while being out of service. The granting of this cash benefit is obligatory while its amount is specified by the administrative authority. Art. 42 (5) Act on the Police specifies a minimum and maximum amount of this cash benefit. Attention was also focused on discussing the legal character of this institution and authorised entities who can use it.

Key words: Police, Police officer, service relationship, (restoration) reinstatement to service, dismissal from the service in the Pfolice, cash benefit for the period of being out of service

Резюме: Статья полностью посвящена институту денежного довольствия, предоставляемого в связи с восстановлением сотрудника полиции на службе в полиции, который содержится в статье 42 раздела 5 Закона от 6 апреля 1990 года «О полиции». Восстановление на службе происходит в силу закона в момент возникновения предпосылок, указанных в статье 42 часть 1 или часть 7 Закона «О полиции». Последствием восстановления в должности является обязательство предоставить сотруднику полиции денежное довольствие за период перерыва в службе. Его предоставление является обязательным, а размер определяется административным органом. Положение статьи 42 (5) Закона «О полиции» устанавливает минимальный и максимальный размер данного довольствия. Также обсуждалась правовая природа этого института и субъекты, имеющие право на его применение.

Ключевые слова: полиция, полицейский, служебные отношения, восстановление на службе, увольнение со службы, денежное довольствие 


\section{Wstęp}

Stosunek służbowy ${ }^{1}$ jest konstrukcją stricte administracyjnoprawną ${ }^{2}, \mathrm{z}$ czego wynika, że jego nawiązanie, zmiana albo też rozwiązanie następuje w drodze kwalifikowanego aktu administracyjnego, jakim jest decyzja administracyjna. Jej istotą jest to, że musi być oparta na wyraźnym przepisie prawa materialnego, który upoważnia do rozstrzygania na tej drodze w określonej kategorii spraw. Zaliczają się do nich niewątpliwie przepisy pragmatyki służbowej dotyczące kwestii zwolnienia ze służby w Policji. Katalog podstaw zwolnienia ze służby w Policji zawarty w ustawie z dnia 6 kwietnia 1990 r. o Policji ${ }^{3}$ ma charakter zamknięty (numerus clausus), z czego wynika, że zwolnienie na innej podstawie jest niedopuszczalne ${ }^{4}$. Sama z kolei de-

1 Jest on formą niepracowniczego zatrudnienia, T. Kuczyński, Wybrane problemy orzecznictwa sądowoadministracyjnego w sprawach z zakresu stosunków służbowych, Zeszyty Naukowe Sądownictwa Administracyjnego 2010, nr 5-6 (32-33), s. 249.

2 Ł. Czebotar i in., Ustawa o Policji. Komentarz, Warszawa 2015, s. 366; P. Gacek, Nawiazanie stosunku służbowego z funkcjonariuszem Policji, Administracja. Teoria, Dydaktyka, Praktyka 2011, nr 2 (23), s. 76 i nn., tenże, Odwołanie od rozkazu personalnego, Przegląd Policyjny 2016, nr 3 (123), s. 80; T. Hanausek i in., Prawo Policyjne. Komentarz, t. 1, red. S. Sagan, Katowice 1992, s. 69; J. Kacprzak, Stosunki stużbowe $w$ formacjach zmilitaryzowanych - charakter prawny, ochrona sadowa, Przegląd Policyjny 1994, nr 1 (33), s. 97; W. Kotowski, Ustawa o Policji. Komentarz, Warszawa 2008, s. 380 i nn.; T. Kuczyński, Wybrane problemy..., s. 250; Leksykon policyjny, red. W. Pływaczewski, G. Kędzierska, Szczytno 2001, s. 304; M. Liwo, Status służb mundurowych i funkcjonariuszy w nich zatrudnionych, Warszawa 2013, s. 311 i nn.; W. Maciejko, Osobowe prawo administracyjne, Warszawa 2008, s. 154; W. Maciejko, A. Korcz-Maciejko, Postępowanie w sprawach osobowych $w$ Policji, Wrocław 2010, s. 20; W. Maciejko, M. Rojewski, A. Suławko-Karetko, Prawo administracyjne. Zarys wykładu części szczególnej, Warszawa 2011, s. 139; J. Paśnik, Prawo dyscyplinarne w Polsce, Warszawa 2000, s. 167; P. Szustakiewicz, Istota stosunku stużbowego, w: Stosunek służbowy w formacjach mundurowych, red. W. Maciejko, P. Szustakiewicz, Warszawa 2016 [wyd. el. Legalis]; T. Szankin, Stużba w Policji, w: Prawo policyjne, red. M. Czuryk i in., Warszawa 2014, s. 200 i nn.; E. Ura, E. Ura, Prawo administracyjne, Warszawa 2004, s. 393; M. Wieczorek, Charakter prawny stosunków służbowych funkcjonariuszy służb mundurowych, Torun 2017, s. 151. Por. także ze stosunkiem służbowym funkcjonariuszy Milicji Obywatelskiej: M. Zorska, Komentarze do ustaw z 31 stycznia 1950 r. o stosunku służbowym funkcjonariuszów Milicji Obywatelskiej i z 31 stycznia 1959 r. o zaopatrzeniu emerytalnym funkcjonariuszów Milicji Obywatelskiej i ich rodzin, Warszawa 1960, s. 10. Jak wynika $\mathrm{z}$ powyższego, pogląd ten został ugruntowany $\mathrm{w}$ doktrynie. Przeciwnie stanowisko prezentuje natomiast T. Hanausek (Ustawa o Policji. Komentarz, Kraków 1996, s. 72), ale jest ono odosobnione. Administracyjnoprawny charakter stosunku służbowego ma istotne znaczenie zarówno w kontekście jego nawiązania, zmiany, rozwiązania, jak i ponownego jego zawiązania w sytuacji przywrócenia do służby, o czym w dalszej części niniejszego opracowania.

3 Ustawa z dnia 6 kwietnia 1990 r. o Policji, tekst jednolity: Dz. U. z 2020 r. poz. 360 z późn. zm.

4 Pragmatyki służbowe mają bowiem charakter zamknięty. Wobec tego subsydiarne stosowanie innych aktów prawnych (należących w szczególności do odrębnych gałęzi prawa) wymaga przepisu szczególnego zawartego w ustawie o Policji, który określa zakres dopuszczalnego stosowania przepisu bądź przepisów usytuowanych poza pragmatyką służbową. Zob. T. Kuczyński, Stosunki służbowe 
cyzja administracyjna, która została wydana bez podstawy prawnej, jest obarczona wadą kwalifikowaną, która determinuje organ administracyjny do wyeliminowania jej z obrotu prawnego na podstawie art. $156 \$ 1$ pkt 2 ustawy z dnia 14 czerwca 1960 r. - Kodeks postępowania administracyjnego 5 . Podstawy prawne zwolnienia ze służby w Policji zostały usystematyzowane $\mathrm{w}$ dwóch grupach, jako obligatoryjne (art. 41 ust. 1 pkt 1-7, a także w art. 41 ust. 3 ustawy o Policji) i fakultatywne (art. 41 ust. 2 pkt 1-9, a także w art. 38 ust. 4 ustawy o Policji) podstawy zwolnienia ze służby w Policji. Każda z nich jest niezależna i niekonkurencyjna w stosunku do pozostałych. Każda też wytycza odrębne granice sprawy administracyjnej w rozumieniu art. 1 K.p.a. Należy przy tym zaznaczyć, że przedmiot postępowania administracyjnego nie może być modyfikowany (rozszerzany lub zmieniany) w jego toku, co oznacza, iż przyjęta podstawa zwolnienia w konkretnej sprawie nie może zostać zmieniona w trakcie trwania tego postępowania. $\mathrm{Z}$ kolei organ administracyjny zobligowany jest do zbadania tylko tych okoliczności, które są objęte przyjętą $\mathrm{w}$ danej sprawie podstawą zwolnienia, wytyczającą granice tej konkretnej sprawy administracyjnej. Nie ma natomiast uprawnienia do wykraczania poza ten zakres, a tym samym do badania tych okoliczności, które nie są relewantne dla tego przedmiotu. Decyzja merytoryczna, która skutkuje zwolnieniem policjanta ze służby w Policji, musi bowiem potwierdzać, że zmaterializował się określony fakt prawotwórczy objęty konkretną podstawą zwolnienia. Ustalenie z kolei braku przesłanki lub przesłanek wynikających z konkretnej podstawy zwolnienia determinuje organ do zakończenia postępowania w sposób formalny, tj. jego umorzenia na podstawie art. $105 \$ 1$ K.p.a. - wobec jego bezprzedmiotowości. Co również istotne, ostateczna decyzja o zwolnieniu ze służby definitywnie rozwiązuje więź prawną pomiędzy funkcjonariuszem a podmiotem zatrudniającym. Pozbawia go tym samym statusu funkcjonariusza Policji.

Są jednak takie przypadki, które powodują uchylenie uprzednio wydanej ostatecznej decyzji o zwolnieniu ze służby, albo też skutkujące tym, że zostanie stwierdzona jej nieważność ${ }^{6}$. Wówczas następuje przywrócenie do służby w Policji na

służb zmilitaryzowanych (mundurowych), w: System Prawa Administracyjnego, t. 11. Stosunek stużbo$w y$, red. R. Hauser, Z. Niewiadomski, A. Wróbel, Warszawa 2011, s. 21; tenże, Wybrane problemy..., s. 260; T. Zieliński, Stosunek prawa pracy do prawa administracyjnego, Warszawa 1977, s. 180, a także uchwałę SN z dnia 5 grudnia 1991 r., I PZP 60/91, Legalis nr 27539 i wyrok NSA z dnia 3 października 2006 r., I OSK 210/06, Legalis nr 606379.

5 Ustawa z dnia 14 czerwca 1960 r. - Kodeks postępowania administracyjnego, tekst jednolity: Dz. U. z 2021 r. poz. 735 (dalej: K.p.a.).

6 Szerzej na ten temat: P. Gacek, Stwierdzenie nieważności rozkazu personalnego o nawiąaniu, zmianie albo rozwiązaniu stosunku służbowego, Państwo i Prawo 2018, z. 8, s. 69 i nn.; tenże, Przesłanki pozytywne stwierdzenia nieważności rozkazu personalnego o nawiązaniu, zmianie albo rozwiązaniu 
stanowisko równorzędne. Służy temu zwarta w art. 42 ustawy o Policji konstrukcja prawna przywrócenia do służby.

Reaktywowanie stosunku służbowego wywołuje wiele konsekwencji w sferze osobowej przywróconego do służby policjanta. Jednym z takich skutków jest nabycie prawa do świadczenia pieniężnego za okres pozostawania poza służbą. Instytucja ta została uregulowana w art. 42 ust. 5 ustawy o Policji. W dalszej części opracowania konieczne będzie udzielenie odpowiedzi na pytanie o charakter tego prawa, chwilę w której to prawo się materializuje, a także podmiot zobowiązany do jej przyznania. Instytucja ta ma, jak się wydaje, istotne znaczenie, bowiem dzięki niej możliwa jest przynajmniej częściowa rekompensata przywróconemu do służby policjantowi ujemnych następstw spowodowanych niezasadnym, albo też wadliwym zwolnieniem ze służby w Policji. Przyjęta przez ustawodawcę konstrukcja prawna, o której mowa, nie ma bowiem charakteru nieograniczonego. Instytucja ta mimo iż stanowi formę pewnej rehabilitacji dla policjanta za niezasadne zwolnienie go ze służby, nie może uwzględniać wyłącznie jego interesu, ale musi zapewnić proporcjonalną i zrównoważoną ochronę zarówno słusznego interesu strony, jak i interesu społecznego. Tylko w ten sposób możliwe jest osiągnięcie celu, dla którego instytucja ta została ustanowiona, tj. słusznego, bo proporcjonalnego zrekompensowania przywróconemu do służby policjantowi niezasadnego zwolnienia z niej. Zamieszczenie jej wyłącznie w jednym artykule ustawy o Policji nie oznacza, że nie wywołuje ona szeregu wątpliwości dla praktyków, którzy zobligowani są do jej stosowania ${ }^{7}$. Stąd też konieczna jest szczegółowa analiza przedmiotowej instytucji, pozwalająca ukazać jej kształt, a także obszary, które budzą wątpliwości w procesie jej stosowania. Przedmiotowe rozważania należy jednak poprzedzić wyjaśnieniem kwestii odnoszącej się do instytucji przywrócenia do służby, bowiem świadczenie pieniężne za okres pozostawania poza służbą przysługuje policjantowi właśnie w związku z takim przywróceniem do służby.

stosunku służbowego z funkcjonariuszem Policji, Administracja. Teoria, Dydaktyka, Praktyka 2016, nr 4 (45), s. 58 i nn.; tenże, Przesłanki negatywne stwierdzenia nieważności rozkazu personalnego o nawiązaniu, zmianie albo rozwiązaniu stosunku stużbowego z funkcjonariuszem Policji, Administracja. Teoria, Dydaktyka, Praktyka 2017, nr 3 (48), s. 5 i nn.

7 Nie można zatem zgodzić się ze stwierdzeniem T. Hanauska, który wskazuje, że treść przepisu art. 42 ustawy o Policji jest jednoznaczna i nie wymaga komentarza, T. Hanausek, Ustawa..., s. 79. 


\section{Konstrukcja prawna określona w art. 42 ust. 5 ustawy o Policji. Przywrócenie do służby w Policji jako podstawa do przyznania świadczenia pieniężnego za okres pozostawania poza służbą}

Jak już wcześniej wspomniano, świadczenie pieniężne za okres pozostawania funkcjonariusza poza służbą immanentnie związane jest z przywróceniem go do służby. Innymi słowy, jest to tryb ${ }^{8}$, który pozwala uprzednio zwolnionemu policjantowi powrócić do pełnienia służby. Warunkiem tego przywrócenia jest jednak uchylenie ostatecznej decyzji o zwolnieniu ze służby ${ }^{9}$ lub wyeliminowanie z obrotu prawnego decyzji administracyjnej o zwolnieniu ze służby w trybie stwierdzenia jej nieważności. Niemniej wyrok sądu administracyjnego, który uchyla ostateczną decyzję o zwolnieniu, musi mieć jednak przymiot prawomocności, natomiast decyzja eliminująca ostateczną decyzję o zwolnieniu przez stwierdzenie jej nieważności musi mieć charakter ostateczny.

Dodać również należy, że przepisy art. 42 ust. 1-6 ustawy o Policji stosuje się odpowiednio w dwóch przypadkach wskazanych w art. 42 ust. 7 pkt 1 i 2 ustawy o Policji. Wynika $\mathrm{z}$ tego, że przywrócenie do służby $\mathrm{w}$ Policji następuje z chwilą, w której zapadło prawomocne orzeczenie, o którym mowa w art. 135s ust. 1 pkt 1 ustawy o Policji, w postępowaniu dyscyplinarnym, które zostało wznowione ze względu na to, że prowadzone przeciwko policjantowi o ten sam czyn postępowanie karne, karne skarbowe lub w sprawach o wykroczenia zostało zakończone prawomocnym wyrokiem uniewinniającym albo orzeczeniem o umorzeniu postępowania ze względu na okoliczności określone w art. 17 $\$ 1$ pkt 1 lub 2 ustawy z dnia 6 czerwca 1997 r. - Kodeksu postępowania karnego $^{10}$, albo $w$ art. $5 \$ 1$ pkt 1 lub 2 ustawy z dnia 24 sierpnia 2001 r. - Kodeksu postępowania $\mathrm{w}$ sprawach o wykroczenia ${ }^{11}$, gdy zwolnienie ze służby nastąpiło na podstawie art. 41 ust. 1 pkt 3 ustawy o Policji, albo też w sytuacji zakończenia postępowania karnego lub karnego skarbowego prawomocnym wyrokiem

8 Jest to jedyny tryb wskazany w pragmatyce służbowej umożliwiający przywrócenie funkcjonariusza do służby w Policji, który został z niej skutecznie zwolniony, zob. wyrok WSA w Warszawie z dnia 11 października 2017 r., II SA/Wa 500/17, Legalis nr 1694970. Por. także M. Nowikowska, Uwagi do art. 42, w: Ustawa o Policji. Komentarz, red. K. Chałubińska-Jentkiewicz, J. Kurek, Warszawa 2020 [wyd. el. Legalis].

9 Nie zaś decyzji uchylającej zaskarżoną decyzję w administracyjnym toku instancji, zob. wyrok WSA w Warszawie z dnia 6 września 2016 r., II SA/Wa 579/16, Legalis nr 1514491.

10 Ustawa z dnia 6 czerwca 1997 r. - Kodeks postępowania karnego, tekst jednolity: Dz. U.z 2021 r. poz. 534 (dalej: K.p.k.).

11 Ustawa z dnia 24 sierpnia 2001 r. - Kodeks postępowania w sprawach o wykroczenia, tekst jednolity: Dz. U. z 2021 r. poz. 457. 
uniewinniającym lub orzeczeniem o umorzeniu postępowania ze względu na okoliczności określone w art. $17 \$ 1$ pkt 1 lub 2 K.p.k., gdy zwolnienie ze służby nastąpiło na podstawie art. 41 ust. 2 pkt 8 i 9 ustawy o Policji.

Zasadą jest więc to, że uchylenie lub stwierdzenie nieważności decyzji o zwolnieniu ze służby w Policji z powodu jej wadliwości stanowi podstawę przywrócenia do służby (art. 41 ust. 1 ustawy o Policji). Przywrócenie do służby może jednak nastąpić również w przypadkach wskazanych w art. 42 ust. 7 pkt 1 i 2 ustawy o Policji. Są to uregulowania stanowiące wyjątek od przyjętej reguły. Konieczne jest bowiem uchylenie w trybie, o którym mowa w art. 135s ustawy o Policji, prawomocnego orzeczenia wydanego w postępowaniu dyscyplinarnym i uniewinnienie ukaranego lub umorzenie postępowania, które stanowiło podstawę do zwolnienia policjanta na podstawie art. 41 ust. 1 pkt 3 ustawy o Policji ${ }^{12}$ (art. 42 ust. 7 pkt 1 ustawy o Policji), bądź też prawomocne zakończenie postępowania karnego lub karnego skarbowego uniewinnieniem policjanta, albo orzeczeniem o jego umorzeniu na podstawie art. $17 \$ 1$ pkt 1 lub 2 K.p.k., jeśli postępowanie karne lub karne skarbowe było przyczyną zwolnienia ze służby na podstawie art. 41 ust. 2 pkt 8 lub 9 ustawy o Policji (art. 42 ust. 7 pkt 2 tej ustawy o Policji). W wymienionych przypadkach przywrócenie do służby następuje w związku z prawomocnym orzeczeniem wydanym po wznowieniu postępowania dyscyplinarnego, albo też w związku z prawomocnym orzeczeniem zapadłym w postępowaniu karnym. Nie następuje więc eliminacja z obrotu prawnego samej decyzji o zwolnieniu ze służby w Policji, która funkcjonuje nadal, lecz nie odnosi ona już skutku prawnego z chwilą, gdy nastąpiło przywrócenie policjanta do służby.

\section{Istota świadczenia pieniężnego za okres pozostawania poza służbą}

Reaktywacja stosunku służbowego następuje z dniem uostatecznienia się albo uprawomocnienia się wskazanych wyżej rozstrzygnięć, bez żadnego udziału policjanta,

12 Zgodnie z art. 134f ustawy o Policji kara wydalenia ze służby oznacza zwolnienie ze służby w Policji. Zwolnienie to nie następuje jednak wskutek wydania samego prawomocnego orzeczenia w postępowaniu dyscyplinarnym wymierzającego tę karę. Przełożony właściwy w sprawach osobowych, po uprawomocnieniu się orzeczenia, niezwłocznie wykonuje karę wydalenia ze służby przez wydanie rozkazu personalnego o zwolnieniu ukaranego policjanta ze służby w Policji (art. 135o ust. 4 ustawy o Policji). Wynika to $\mathrm{z}$ administracyjnoprawnego charakteru stosunku służbowego, którego nawiązanie, zmiana oraz rozwiązanie może nastąpić wyłącznie w drodze kwalifikowanego aktu administracyjnego, tj. decyzji administracyjnej. 
którego one dotyczą ${ }^{13}$. Przywrócenie do służby już od chwili, w której ponownie zainicjowało stosunek służbowy, materializuje prawo przywróconego policjanta do świadczenia, o którym mowa w art. 42 ust. 5 ustawy o Policji. I chociaż ponownie zawiązany stosunek służbowy nie ma charakteru trwałego, bo wymaga od przywróconego do służby policjanta wypełnienia warunku, o którym mowa wart. 42 ust. 2 ustawy o Policji, a po skutecznym jego spełnieniu zweryfikowania jego przymiotów w kontekście możliwości dalszego świadczenia służby (art. 42 ust. 3 ustawy o Policji), to należy podkreślić, że prawo do świadczenia pieniężnego za okres pozostawania poza służbą nie jest uzależnione od zgłoszenia przez przywróconego do służby policjanta gotowości niezwłocznego jej podjęcia, o którym mowa w art. 42 ust. 2 ustawy o Policji, jak również od wyniku jego weryfikacji, o której mowa w art. 42 ust. 3 ustawy o Policji. Prawo do tego świadczenia w całości uzależnione jest wyłącznie od jednego faktu prawotwórczego, który je materializuje, a jest nim przywrócenie do służby i to niezależnie od tego, czy ma ono charakter czasowy, czy też trwały. Należy bowiem podkreślić, że przywrócenie do służby następuje bez zgody, a może także nastąpić wbrew woli samego zainteresowanego, tj. z mocy samego prawa. Stąd też ponownie zaistniała więź prawna (stosunek służbowy) nie może mieć charakteru trwałego do czasu potwierdzenia gotowości dobrowolnego jej pełnienia przez przywróconego do służby policjanta. Przywrócenie do służby reaktywuje również więź służbową. Przywrócony policjant od tego momentu posiada przełożonego właściwego w sprawach osobowych. Przywrócony do służby funkcjonariusz na powrót nabywa przymiot policjanta, chociaż nie może być dopuszczony do służby do czasu zweryfikowania jego przymiotów niezbędnych do pełnienia służby w Policji i mianowania go na konkretne stanowisko służbowe, pod warunkiem jednak spełnienia przez niego uprzednio warunku wynikającego z art. 42 ust. 2 ustawy o Policji. To ten przełożony właściwy w sprawach osobowych jest zobligowany do przyznania przywróconemu do służby policjantowi świadczenia pieniężnego za okres pozostawania poza służbą. Ponieważ prawo to materializuje się wraz z przywróceniem policjanta do służby, rozstrzygnięcie w tym zakresie winno być wydane niezwłocznie po ponownym zawiązaniu się stosunku służbowego, bo jest ono od tego dnia wymagalne. Wobec tego przełożony właściwy w sprawach osobowych zobowiązany jest do niezwłocznego wydania rozstrzygnięcia w tej sprawie, po uzyskaniu informacji w tym zakresie oraz jej należytym zweryfikowaniu.

13 Ł. Czebotar i in., Ustawa o Policji..., s. 433 i nn. 


\section{Decyzja administracyjna w sprawie przyznania świadczenia pieniężnego za okres pozostawania poza służbą}

Przełożony właściwy w sprawach osobowych zobligowany jest do wydania rozstrzygnięcia o przyznaniu przywróconemu do służby policjantowi świadczenia pieniężnego, o którym mowa w art. 42 ust. 5 ustawy o Policji. Decyzja w tym zakresie ma charakter związany ${ }^{14}$, co oznacza, że wymieniony przepis nie przewiduje sytuacji, w której można byłoby wydać rozstrzygnięcie, które odmawiałoby policjantowi przyznania tego świadczenia, mimo prawnie skutecznego przywrócenia go do służby ${ }^{15}$. Jak już wcześniej wskazano, przywrócenie do służby następuje z mocy prawa i nie wymaga żadnego udziału ze strony przywróconego policjanta lub jego przełożonego właściwego w sprawach osobowych. Jednym natomiast ze skutków tego przywrócenia jest powstanie prawa po stronie tego policjanta do świadczenia pieniężnego za okres pozostawania poza służbą. Argumentację tę wzmacnia również treść przepisu art. 42 ust. 5 ustawy o Policji, z którego wynika, że policjantowi przywróconemu do służby przysługuje za okres pozostawania poza służbą świadczenie pieniężne. Bezsprzecznie zatem wyłączono możliwość uznaniowego traktowania tej kwestii przez organ administracyjny. Gdyby wolą ustawodawcy było przyznanie przełożonemu właściwemu w sprawach osobowych kompetencji do rozstrzygania w kwestii przyznania bądź odmowy przyznania tego świadczenia, w sytuacji skutecznego przywrócenia do służby, wówczas treść tego przepisu wskazywałaby, iż policjantowi przywróconemu do służby „może” zostać przyznane świadczenie pieniężne za okres pozostawania poza służbą. W przeciwieństwie do instytucji przywrócenia do służby, niewymagającej wydania rozstrzygnięcia, którego przedmiotem byłoby to przywrócenie, bo następuje ono ipso iure $\mathrm{z}$ chwilą zmaterializowania się przesłanek wskazanych $\mathrm{w}$ art. 41 ust. 1 albo ust. 7 ustawy o Policji, przyznanie świadczenia pieniężnego za okres pozostawania

14 „[...] każdorazowe przywrócenie policjanta do służby, powoduje po stronie organu powinność przyznania świadczenia pieniężnego za okres pozostawania poza służbą", wyrok WSA w Lublinie z dnia 22 grudnia 2011 r., III SA/Lu 355/11, Legalis nr 439943, zob. także Ł. Czebotar i in., Ustawa o Policji..., s. 436.

15 Nie można zatem zgodzić się ze stanowiskiem doktryny, z którego wynika, że: „Decyzja o przyznaniu świadczenia z art. 42 ust. 5 ustawy o Policji ma charakter uznaniowy [...]”, B. Opaliński, M. Rogalski, P. Szustakiewicz, Uwagi do art. 42, w: Ustawa o Policji. Komentarz, wyd. 1, Warszawa 2015 [wyd. el. Legalis]; w tym samym tonie M. Nowikowska, Uwagi do art. 42. Decyzja w zakresie przyznania świadczenia pieniężnego ma bezwzględnie charakter związany, po ustaleniu przez organ, iż policjant został przywrócony do służby. Uznaniowość istnieje jedynie w płaszczyźnie ustalenia wysokości tego świadczenia, ale w granicach określonych przez art. 42 ust. 5 ustawy o Policji. 
policjanta poza służbą następuje w drodze kwalifikowanego aktu administracyjnego, jakim jest decyzja administracyjna.

Kwestia dotycząca świadczenia pieniężnego, o którym mowa w art. 42 ust. 5 ustawy o Policji, niewątpliwie stanowi sprawę osobową w rozumieniu $₫ 1$ pkt 4 rozporządzenia Ministra Spraw Wewnętrznych z dnia 14 maja 2013 r. w sprawie szczegółowych praw i obowiązków oraz przebiegu służby policjantów ${ }^{16}$. Są nimi bowiem sprawy związane z nawiązaniem, zmianą i rozwiązaniem stosunku służbowego oraz wynikającymi z jego treści prawami i obowiązkami policjantów. I chociaż $\$ 3$ przywołanego rozporządzenia, który stanowi pewną egzemplifikację spraw osobowych, nie wymienia wprost świadczenia $\mathrm{z}$ art. 42 ust. 5 ustawy o Policji jako sprawy osobowej, to nie może budzić wątpliwości, że instytucja, o której mowa, stanowi sprawę osobową, gdyż jest bezpośrednio związana $\mathrm{z}$ reaktywacją (ponownym zawiązaniem się) wadliwie rozwiązanego stosunku służbowego. Jest prawem przywróconego policjanta immanentnie związanym z faktem przywrócenia do służby, lub, innymi słowy, z faktem ponownego jego nawiązania. Na marginesie należy również wskazać, że $\$ 3$ rozporządzenia z dnia 14 maja 2013 r. stanowi wyłącznie przykładowe wyliczenie spraw kwalifikowanych jako sprawy osobowe. Jest to katalog otwarty, o czym dobitnie świadczy użyte w tekście tego przepisu sformułowanie „w szczególności” usytuowane przed wyliczeniem spraw stanowiących sprawę osobową. Wynika z tego, że inne sprawy niewymienione tym przepisem mogą być sprawami osobowymi, o ile związane są z nawiązaniem, zmianą albo rozwiązaniem stosunku służbowego, bądź z wynikających $\mathrm{z}$ jego treści praw i obowiązków policjantów. Jest to o tyle istotne, że zgodnie $\mathrm{z} \$ 19$ ust. 2 rozporządzenia $\mathrm{z}$ dnia 14 maja $2013 \mathrm{r}$. do postępowania w sprawach osobowych dotyczących nawiązania, zmiany i rozwiązania stosunku służbowego w zakresie nieuregulowanym rozporządzeniem stosuje się przepisy Kodeksu postępowania administracyjnego. Zakres odesłania do K.p.a. w sprawach osobowych ma charakter ograniczony, bowiem dotyczyć może tylko nawiązania, zmiany i rozwiązania stosunku służbowego. Należy jednak zaznaczyć, że sam przepis art. 42 ustawy o Policji nie wskazuje, w jaki sposób następuje konkretyzacja prawa do świadczenia pieniężnego dla przywróconego do służby policjanta, a samo przywrócenie następuje z mocy prawa, bez konieczności wydania w tym zakresie rozstrzygnięcia o tym przywróceniu. Z kolei świadczenie pieniężne, o którym mowa w art. 42 ust. 5 ustawy o Policji, jest bezpośrednio związane z przywróceniem (ponownym nawiązaniem stosunku służbowego). Zatem zasadne wydaje się stwierdzenie, iż w tej konkretnej sytuacji, ta sprawa

16 Rozporządzenie Ministra Spraw Wewnętrznych z dnia 14 maja 2013 r. w sprawie szczegółowych praw i obowiązków oraz przebiegu służby policjantów, Dz. U. z 2020 r. poz. 113 (dalej: rozporządzenie z dnia 14 maja 2013 r.). 
osobowa, jako bezpośrednio związana z nawiązaniem (reaktywacją) stosunku służbowego, winna być rozstrzygana na zasadach i w trybie określonym w K.p.a.

Decyzja w sprawie przyznania świadczenia pieniężnego nosi nazwę rozkazu personalnego ${ }^{17}$. Sama nazwa nie ma jednak aż tak dużego znaczenia. Rozstrzygnięcie może również nosić nazwę decyzji. W obu przypadkach niewątpliwie będą one decyzjami administracyjnymi. Ważna jest natomiast treść samego rozstrzygnięcia zawartego w jej osnowie. Musi z niej wynikać w sposób niebudzący wątpliwości, że organ przyznaje bądź odmawia przyznania świadczenia pieniężnego za okres pozostawania poza służbą przez przywróconego do niej policjanta. W przypadku jego przyznania istotne jest to, że rozstrzygnięcie nie określa kwotowo wysokości tego świadczenia, a jedynie wskazuje, czy przysługuje ono przywróconemu do służby policjantowi, a także określa jego wymiar jako świadczenia pieniężnego równego uposażeniu na stanowisku zajmowanym przed zwolnieniem ze służby w Policji za okres od jednego miesiąca do sześciu miesięcy. Ustalenie kwotowe wysokości przyznanego świadczenia jest czynnością stricte materialno-techniczną, wykonywaną przez komórki organizacyjne właściwe w sprawach finansowych jednostek Policji. Nieprawidłowym byłoby wskazanie w decyzji wyłącznie kwoty przyznanego świadczenia pieniężnego. Należałoby wówczas zweryfikować, czy odpowiada ono uposażeniu przywróconego do służby policjanta na stanowisku zajmowanym przed zwolnieniem ze służby w Policji w wymiarze określonym w przepisie art. 42 ust. 5 ustawy o Policji. Nie jest bowiem dopuszczalne przyznanie świadczenia pieniężnego, które byłoby niższe od uposażenia za jeden miesiąc albo wyższe od uposażenia za sześć miesięcy. Taka decyzja rażąco naruszyłaby dyspozycję normy prawnej wynikającej z art. 42 ust. 5 ustawy o Policji, wskutek czego konieczne byłoby wyeliminowanie jej z obrotu prawnego na podstawie art. $156 \$ 1$ pkt 2 K.p.a., jako decyzji obciążonej wadą kwalifikowaną.

\section{Okoliczności mające wpływ na wysokość przyznanego świadczenia pieniężnego}

Warto zaznaczyć, że choć samo przyznanie świadczenia pieniężnego, o którym mowa w art. 42 ust. 5 ustawy o Policji, jest obligatoryjne, to określenie jego wysokości zostało pozostawione uznaniu administracyjnemu ${ }^{18}$. Zastrzec jednak należy,

17 Zob. $\$ 3$ ust. 3 rozporządzenia z dnia 14 maja $2013 \mathrm{r}$

18 „Zgodnie z art. 42 ust. 5 ustawy z dnia 6 kwietnia 1990 r. o Policji (t.j. Dz. U. z 2007 r. Nr 43, poz. $277 \mathrm{ze}$ zm.) policjantowi przywróconemu do służby przysługuje za okres pozostawania poza służbą świadczenie pieniężne równe uposażeniu na stanowisku zajmowanym przed zwolnieniem 
że musi ono mieścić się w granicach minimum i maksimum wyznaczonego przez art. 42 ust. 5 ustawy o Policji. Świadczenie, o którym mowa, ma charakter rekompensacyjny ${ }^{19}$. Jest pewną formą odszkodowania za niezgodne z prawem rozwiązanie stosunku służbowego ${ }^{20}$. Zatem przy ustaleniu jego wymiaru należy brać pod uwagę okoliczności towarzyszące zwolnieniu ze służby w Policji, które wywarły wpływ na sferę ekonomiczną policjanta ${ }^{21}$. Wymagają również uwzględnienia te świadczenia, które policjant otrzymał w związku z tym zwolnieniem (odprawa, ekwiwalent za niewykorzystane urlopy, a także za czas służby w wymiarze ponadnormatywnym). Ocenie podlega też jego sytuacja socjalno-bytowa w okresie od zwolnienia do dnia przywrócenia do służby (czy był w tym okresie bezrobotnym z prawem albo bez prawa do zasiłku, czy podjął inne zatrudnienie lub inną aktywność mającą cel zarobkowy, albo czy pozostawał na zaopatrzeniu emerytalnym lub rentowym). Nie ma natomiast istotnego znaczenia sama długość okresu jego pozostawania poza służbą ${ }^{22}$. Jak zaznacza judykatura, „świadczenie to ma czynić zadość konsekwencjom

nie więcej niż za okres 6 miesięcy i nie mniej niż za jeden miesiąc. Przepis ten gwarantuje funkcjonariuszowi przywróconemu do służby świadczenie równe w swej podstawie uposażeniu, jakie otrzymywał na zajmowanym stanowisku przed zwolnieniem, przy czym chodzi tu o miesięczne uposażenie funkcjonariusza, jakie przysługiwało mu na zajmowanym stanowisku przed zwolnieniem ze służby, mnożone przez liczbę miesięcy, nie więcej jednak niż 6 miesięcy i nie mniej niż 1 miesiąc. Taka konstrukcja przepisu wskazuje, że ustawodawca gwarantuje jedynie funkcjonariuszowi prawo do świadczenia, natomiast wysokość tego świadczenia pozostawia uznaniu organu administracji, ograniczając je co do minimum i maksimum" - wyrok WSA w Warszawie z dnia 7 czerwca 2011 r., II SA/Wa 392/11, Legalis nr 342851, a także wyrok WSA w Warszawie z dnia 29 listopada 2007 r., II SA/Wa 1611/07, Legalis nr 292963.

19 Ł. Czebotar i in., Ustawa o Policji..., s. 436; W. Maciejko, A. Korcz-Maciejko, Postępowanie..., s. 339. „Przewidziane nim świadczenie ma charakter rekompensacyjny, odszkodowawczy, a jego wysokość relatywizowana jest wprost do wysokości uposażenia funkcjonariusza” - wyrok SA w Szczecinie I Wydział Cywilny z dnia 27 marca 2019 r., I ACa 520/18, Legalis nr 2180740, a także wyrok WSA w Łodzi z dnia 3 sierpnia 2018 r., III SA/Łd 235/18, Legalis nr 1814940; wyrok NSA z dnia 10 marca 2016 r., I OSK 2533/14, Legalis nr 1455932; wyrok NSA z dnia 14 października 2015 r., I OSK 327/14, Legalis nr 1387238; wyrok WSA w Lublinie z dnia 22 grudnia 2011 r., III SA/Lu 355/11, Legalis nr 439943; wyrok WSA w Poznaniu z dnia 25 listopada 2009 r., II SA/Po 400/09, Legalis nr 343653; wyrok NSA z dnia 4 czerwca 2008 r., I OSK 915/07, Legalis nr 165765; wyrok WSA w Warszawie z dnia 29 listopada 2007 r., II SA/Wa 1611/07, Legalis nr 292963; wyrok WSA w Gliwicach z dnia 10 września 2007 r., IV SA/Gl 187/07, Legalis nr 113217.

20 Wyrok WSA w Warszawie z dnia 16 października 2017 r., II SA/Wa 303/17, Legalis nr 1691823.

21 Kryterium decydującym o przyznaniu tego świadczenia pieniężnego są okoliczności dotyczące sytuacji finansowej osoby zwolnionej w okresie od dnia jej zwolnienia do dnia przywrócenia do służby, a organ zobowiązany jest ustalić, jakie skutki w sferze majątkowej spowodowało zwolnienie funkcjonariusza ze służby, zob. wyrok SA w Szczecinie - I Wydział Cywilny z dnia 27 marca 2019 r., I ACa 520/18, a także W. Maciejko, A. Korcz-Maciejko, Postępowanie..., s. 339.

22 „Każdorazowe przywrócenie policjanta do służby powoduje po stronie organu obowiązek przyznania świadczenia pieniężnego za okres pozostawania poza służbą. Kryterium decydującym w tego rodzaju 
pozostawania poza służbą zwłaszcza w najbardziej odczuwalnej sferze ekonomicznej, zatem wymiar świadczenia winien uwzględniać sytuację finansową policjanta po zwolnieniu ze służby i być wprost proporcjonalny do wysokości świadczeń otrzymanych w związku ze zwolnieniem, a także pobieranych po zwolnieniu”23.

Organ administracyjny zobowiązany jest zatem wziąć pod uwagę cały zgromadzony materiał dowodowy świadczący o tym, czy sytuacja finansowa policjanta po jego zwolnieniu uległa bądź nie uległa zasadniczemu pogorszeniu. Świadczenia pieniężne z tytułu zwolnienia ze służby w Policji, jak również przyznane w związku z tym zwolnieniem, a także te przysporzenia majątkowe, które zwolniony policjant pozyskiwał po zwolnieniu ze służby (związane z nowym zatrudnieniem, emeryturą, rentą albo innymi formami aktywności związanej z zarobkowaniem) mają bezsprzecznie wpływ na sytuację socjalną, w jakiej znajduje się policjant, który zostaje zwolniony ze służby w Policji. Inna interpretacja, która prowadziłaby do pominięcia niektórych z wymienionych wyżej okoliczności, a zarazem do uwzględnienia tylko tych, które byłyby korzystne dla strony postępowania administracyjnego w sprawie przyznania tego świadczenia, prowadziłaby do naruszenia istoty przyznanej organowi administracyjnemu kompetencji do działania w granicach uznania administracyjnego, która co prawda obliguje ten organ do uwzględnienia słusznego interesu strony, ale nie zwalnia tego organu z konieczności równoważenia go interesem społecznym. Nie można bowiem w sposób arbitralny deprecjonować interesu społecznego, a takim byłoby pominięcie niektórych okoliczności relewantnych dla przedmiotu postępowania administracyjnego w tej sprawie. Skutkowałoby to wydaniem decyzji nie uznaniowej, ale dowolnej, bo uwzględniającej w sposób arbitralny wyłącznie partykularny interes przywróconego do służby policjanta. Należy zaakcentować, iż wysokość świadczenia winna stanowić adekwatną rekompensatę przysługującą w zamian za zwolnienie ze służby. Co do zasady, samo zwolnienie ze służby nie musi bowiem ipso facto skutkować brakiem

przypadkach są okoliczności dotyczące sytuacji finansowej osoby zwolnionej w okresie od dnia jej zwolnienia do dnia przywrócenia do służby, nie zaś jedynie długość pozostawania poza służbą” wyrok NSA z dnia 21 sierpnia 2013 r., I OSK 803/13, Legalis nr 764726, a także wyrok WSA w Łodzi z dnia 3 sierpnia 2018 r., III SA/Łd 235/18, Legalis nr 1814940.

23 Wyrok WSA w Łodzi z dnia 3 sierpnia 2018 r., III SA/Łd 235/18. Porównaj także z wyrokiem NSA z dnia 10 marca 2016 r., I OSK 2533/14: „Świadczenie pieniężne za okres pozostawania poza służbą, określone w art. 42 ust. 5 ustawy z dnia 6 kwietnia 1990 r. o Policji (t.j. Dz. U. z 2015 r. poz. 355) ma czynić zadość konsekwencjom pozostawania poza służbą zwłaszcza w najbardziej odczuwalnej sferze ekonomicznej [...]. Oznacza to, że ma za zadanie wyrównać poniesioną przez funkcjonariusza szkodę w związku ze zwolnieniem ze służby. Rozstrzygając o przyznaniu tego świadczenia organ ma obowiązek zweryfikować, jakie skutki w sferze finansowej spowodowało zwolnienie funkcjonariusza ze służby", a także z wyrokiem WSA w Lublinie z dnia 22 grudnia 2011 r., III SA/Lu 355/11, Legalis $\mathrm{nr} 439943$ i z wyrokiem WSA w Warszawie z dnia 7 czerwca 2011 r., II SA/Wa 392/11, Legalis nr 342851 . 
możliwości podjęcia innych form zarobkowania przez zwolnionego policjanta, w tym wykonywania innych zajęć zarobkowych. Tym samym nie każde zwolnienie ze służby musi automatycznie powodować pogorszenie sytuacji materialnej zwolnionego policjanta, zwłaszcza jeśli zwolnienie to łączy się z przyznaniem mu określonych świadczeń pieniężnych, jak również z możliwością uzyskiwania dochodów z innych źródeł, które związane są z podjęciem nowego zatrudnienia, z emeryturą, z rentą lub z innego rodzaju aktywnością, która przynosi takiej osobie określone korzyści majątkowe, które, co należy również zaznaczyć, mogą (nie można tego wykluczyć) przewyższać te (tj. uposażenie i inne świadczenia związane ze służbą), które otrzymywał on, będąc czynnym funkcjonariuszem.

Nie można jednak przy dokonywanej ocenie uwzględniać tych zobowiązań, które dobrowolnie zaciągnął sam policjant i które skutkowały tym, iż mimo otrzymanych w związku ze zwolnieniem ze służby świadczeń jego sytuacja finansowa uległa znacznemu pogorszeniu, a które nie były dla niego niezbędne. Korzystanie z przysługujących uprawnień do swobodnego rozporządzania poszczególnymi składnikami posiadanego majątku, zaciągania różnego rodzaju zobowiązań, a także składania różnego rodzaju oświadczeń woli jest prawem osoby, nie zaś jej obowiązkiem. Ewentualne niekorzystne skutki wywołane działaniem takiej osoby nie mogą automatycznie determinować do uwzględnienia ich przez organ jako tych, które wywołały negatywne konsekwencje w sferze socjalnej zwolnionego ze służby policjanta. Nie stanowią one bowiem takich zobowiązań, jakimi są np. zobowiązania publicznoprawne, których realizacja jest obowiązkiem podmiotu, którego dotyczą i które mogą powstać wskutek zdarzeń niezależnych od woli i wiedzy osoby, której dotyczą, a których niewykonanie może być sankcjonowane odrębnymi przepisami mającymi nawet charakter karny. Jeśli natomiast osoba sama z własnej woli zaciąga zobowiązania lub składa innego rodzaju oświadczenia woli, to robi to w celu zabezpieczenia swojego interesu. Tym samym musi liczyć się z ewentualnymi konsekwencjami, jakie jej działania mogą wywołać w jej sytuacji majątkowej, ponosi ona bowiem związane z tym ryzyko. Zatem jeśli takie rozporządzenie mieniem nie ma charakteru nieodzownego, tj. nie ma na celu zabezpieczenia życia, zdrowia, bytu rozporządzającego nim, a także mienia przed większymi stratami, to jego skutki nie mogą wpływać na decyzje organu administracyjnego. W konsekwencji takie rozporządzenie nie może być brane pod uwagę przez organ jako świadczące o pogorszeniu sytuacji socjalno-bytowej osoby, której ma być ono przyznane. Nie jest bowiem rolą organu ocena swobodnego gospodarowania przez stronę przyznanymi mu środkami finansowymi, a także posiadanym mieniem. Ocena zasadności tych działań nie pozostaje w gestii organu administracyjnego. Jest on zobowiązany wyłącznie do uwzględnienia obiektywnych okoliczności związanych z sytuacją 
finansową i bytową, w jakiej znalazł się policjant w związku z jego zwolnieniem ze służby. Ocena ta nie może rozciągać się natomiast na sytuacje, w których były policjant niekorzystnie rozdysponował (dystrybuował) przyznanymi mu środkami, wskutek czego swoim działaniem doprowadził do pogorszenia swojej sytuacji bytowej. Określając wysokość przyznanego świadczenia, organ zobligowany jest natomiast do ustalenia szeroko rozumianej sytuacji finansowej, w jakiej znalazł się policjant w związku ze zwolnieniem ze służby, bowiem ma ono rekompensować tej osobie to, że znalazła się ona w określonej sytuacji faktycznej wywołanej tym zwolnieniem. Nie stanowi natomiast rekompensaty za podjętą przez nią w dobrowolny sposób aktywność po zwolnieniu, która miała niekorzystny wpływ na jej sytuację finansową. Odmienne stanowisko w tym zakresie prowadziłoby to tego, że osoba, która dobrowolnie niekorzystnie rozdysponowała swoim mieniem, musiałaby być potraktowana przez organ w sposób uprzywilejowany w stosunku do osoby, która posiadała porównywalną sytuację finansową, ale powstrzymała się z takim niekorzystnym rozporządzeniem mienia.

Nie sposób jednak odnieść się do wszystkich stanów faktycznych, które mogą zaistnieć w tego rodzaju sprawach. Niemniej należy zaznaczyć, że każdy przypadek winien być traktowany w sposób indywidualny, a ocena dotycząca wysokości przyznanego świadczenia pieniężnego winna być podjęta na podstawie całokształtu zebranego w sprawie materiału dowodowego, a następnie dostatecznie uzasadniona $w$ treści decyzji administracyjnej, ponieważ uzasadnienie to musi świadczyć o działaniu właściwego organu w ramach uznania administracyjnego, którego granice wytycza art. 7 K.p.a., natomiast osoba, której świadczenie ma być przyznane, musi zostać przekonana, że jego wysokość spełniła zakładany przez ustawodawcę cel.

\section{Zakończenie}

Obecnie obowiązująca regulacja zawarta w art. 42 ustawy o Policji stanowi instrument prawny mający zapewnić gwarancje poszanowania słusznych praw tych funkcjonariuszy Policji zwolnionych ze służby w Policji, którzy wskutek zaistnienia przesłanek wymienionych $\mathrm{w}$ tym przepisie zostali następnie do niej przywróceni. Konstrukcja zawarta w art. 42 ust. 5 ustawy o Policji stanowi pewną formę rehabilitacji w zamian za niezasadne (bądź niesłuszne) rozwiązanie stosunku służbowego. Należy mieć jednak na uwadze, co zostało zaznaczone, że każda instytucja prawna musi zapewniać proporcjonalną ochronę nie tylko 
słusznego interesu strony, tj. zwolnionego, a następnie przywróconego do służby funkcjonariusza, ale również interesu społecznego, bowiem musi być zdatnym środkiem do osiągnięcia zamierzonego przez ustawodawcę celu, jakim jest proporcjonalna i słuszna rekompensata za zwolnienie ze służby w Policji. Wykładnia przepisu art. 42 ustawy o Policji, i to zarówno językowa, jak i funkcjonalna oraz celowościowa, wskazuje wprost, że zamiarem ustawodawcy było objęcie zakresem tej konstrukcji prawnej możliwie jak największej ilości stanów faktycznych. Tym samym mechanizm pozwalający na rekompensatę za okres pozostawania funkcjonariusza poza służbą także musi posiadać formułę uniwersalną, która może być odniesiona do sytuacji, w której materializują się przesłanki zastosowania tej instytucji. Stąd też wprowadzony obowiązek przyznania tego świadczenia każdemu policjantowi przywracanemu do służby w tym trybie. Uznaniowość dotyczy wyłącznie kwestii wysokości przyznanego świadczenia. Organ musi zbadać, w jakiej sytuacji materialnej znalazł się zwolniony policjant w związku z tym zwolnieniem, a w szczególności czy wskutek tego zwolnienia nastąpiło jej pogorszenie. Rozstrzygnięcie tej kwestii musi gwarantować rekompensatę proporcjonalną i zasadną $\mathrm{z}$ punktu widzenia podjętej $\mathrm{w}$ stosunku do niego w przeszłości decyzji personalnej. Automatyzm w tym zakresie nie gwarantuje bowiem przyznania świadczenia w pełni rekompensującego ujemne następstwa rozwiązania stosunku służbowego. Nie można jednak a limine zakładać, aby każde zwolnienie ze służby (w tym także niezasadne) wiązało się z pogorszeniem sytuacji materialnej zwalnianego policjanta. Otrzymuje on bowiem pewne świadczenia $\mathrm{z}$ tytułu tego zwolnienia, albo też związane $\mathrm{z}$ tym zwolnieniem, które wchodzą w skład jego majątku, jakim może dysponować w celu zabezpieczenia swojej sytuacji bytowej. Nie mogą jednak być branie pod uwagę te zdarzenia, które doprowadziły zwolnionego policjanta do rozdysponowania tym mieniem i zaciągnięcia zobowiązań, które nie skutkowały nie tylko osiągnięciem przez niego założonego zysku, ale również które spowodowały uszczuplenie jego stanu majątkowego, lecz nie były dla niego nieodzowne (niezbędne, obowiązkowe). Jako że zobowiązania te były wynikiem wyłącznie jego aktywności, to jedynie on ponosi ryzyko ich przedsięwzięcia. Organ zobowiązany jest natomiast do uwzględnienia tych okoliczności, za które zwolniony policjant nie ponosi odpowiedzialności i którym nie mógł zapobiec, a zatem za takie obciążenia (w tym zobowiązania publicznoprawne), które zobowiązany jest ponosić niezależnie od swojej woli, a także za te, których skutki zostały wywołane przez siłę wyższą. Nie może natomiast osoba, której przyznano świadczenia o określonej wysokości, podnosić, iż dokonała rozporządzenia mieniem, które stało się w konsekwencji niekorzystne i w ten sposób jej sytuacja materialna po zwolnieniu ze służby 
uległa pogorszeniu. Źródło bowiem uszczuplenia majątkowego nie tkwiło bezpośrednio w zwolnieniu, ale w samej aktywności osoby, która dobrowolnie ją podjęła. Taka $\mathrm{z}$ kolei okoliczność nie może determinować przyznania świadczenia pieniężnego w zwiększonej wysokości.

Na sytuację majątkową wpływa także to, czy zwolniony policjant utracił zdolność do podjęcia innej pracy (służby) lub innej działalności (aktywności) o charakterze zarobkowym albo czy taką pracę (służbę) lub inną aktywność podjął niezwłocznie po zwolnieniu bądź po określonym czasie. Może ona bowiem przynieść większy dochód niż ten, który był mu należny jako czynnemu funkcjonariuszowi za pełnioną przez niego służbę. Zwolniony policjant posiadający uprawnienia emerytalne lub rentowe może uzyskiwać również dochód z tytułu emerytury lub renty. Osoba taka może także podejmować dodatkowe zatrudnienie lub inną działalność o charakterze zarobkowym, które łącznie mogą przynosić większy dochód niż uposażenie za pełnioną służbę przed zwolnieniem. To również z oczywistych względów ma wpływ na jego sytuację majątkową i może w sposób dostateczny uzasadniać twierdzenie, że nie uległa ona pogorszeniu. Automatyczne przyznanie świadczenia pieniężnego w najwyższej dopuszczalnej wysokości, bez uwzględnienia wszelkich okoliczności związanych z sytuacją majątkową zwolnionego policjanta, które wystąpiły w związku z tym zwolnieniem, mogłoby się jawić jako świadczenie, którego wysokość jest niezasadna i nieproporcjonalna do rekompensacyjnego celu, jaki przez jego przyznanie ma być osiągnięty.

Obligatoryjność przyznania świadczenia pieniężnego w sytuacji przywrócenia do służby, a także uprawnienie do miarkowania jego wysokości w granicach od jedno- do sześciomiesięcznego uposażenia stanowi zatem dostateczną gwarancję tego, że żaden policjant przywrócony do służby nie zostanie pozbawiony pewnej rekompensaty za niesłuszne z niej zwolnienie. Dodać przy tym należy, że jeśli strona jest niezadowolona $z$ wysokości przyznanego jej świadczenia i w jej ocenie nie stanowi ona dostatecznej rekompensaty, to może takie rozstrzygnięcie kwestionować zarówno w administracyjnym toku instancji, jak również na drodze sądowoadministracyjnej.

Nie można też tracić z pola widzenia drogi cywilnoprawnej dla dochodzenia roszczeń przez osobę, która $\mathrm{z}$ określonych zdarzeń wywodzi skutki prawne w postaci przysługującego jej roszczenia. W tych sytuacjach jednak ciężar dowodzenia spoczywa na osobie, która z określonych zdarzeń wywodzi skutki prawne. Ścieżka ta pozwala także zagwarantować, że nawet w sytuacji ustalenia i przyznania przez organ administracyjny rekompensaty w wysokości nieadekwatnej w stosunku do oczekiwań strony, które nie zostały całkowicie zaspokojone przyznanym świadczeniem pieniężnym, o którym mowa w art. 42 ust. 5 ustawy o Policji, ustalona przez 
sąd cywilny w wyroku wysokość roszczenia będzie w pełni odzwierciedlać zakres i rozmiar szkody wyrządzonej w wyniku niezasadnego zwolnienia ${ }^{24}$.

Przyjęte przez ustawodawcę rozwiązanie zawarte w art. 42 ust. 5 ustawy o Policji jawi się wobec podniesionych argumentów jako optymalna konstrukcja umożliwiająca uwzględnienie zarówno partykularnego interesu strony, jak i interesu społecznego. $\mathrm{Z}$ jednej strony instytucja ta ma spełniać rolę rekompensaty dla przywróconego do służby policjanta za niezasadne zwolnienie go $\mathrm{z}$ tej służby, z drugiej musi chronić interes fiskalny państwa. Stąd też wprowadzone ograniczenie co do wysokości świadczenia, które ma być przyznane. Jest to zasadne, bowiem nie można założyć a limine, że gdyby policjant nie został zwolniony ze służby, pełniłby ją przez cały okres, w jakim pozostawał poza służbą.

\section{Bibliografia}

Czebotar Ł. i in., Ustawa o Policji. Komentarz, Warszawa 2015.

Gacek P., Nawiązanie stosunku stużbowego z funkcjonariuszem Policji, Administracja. Teoria, Dydaktyka, Praktyka 2011, nr 2 (23).

Gacek P., Odwołanie od rozkazu personalnego, Przegląd Policyjny 2016, nr 3 (123).

Gacek P., Przesłanki negatywne stwierdzenia nieważności rozkazu personalnego o nawiazaniu, zmianie albo rozwiązaniu stosunku stużbowego z funkcjonariuszem Policji, Administracja. Teoria, Dydaktyka, Praktyka 2017, nr 3 (48).

Gacek P., Przesłanki pozytywne stwierdzenia nieważności rozkazu personalnego o nawiązaniu, zmianie albo rozwiązaniu stosunku stużbowego z funkcjonariuszem Policji, Administracja. Teoria, Dydaktyka, Praktyka 2016, nr 4 (45).

Gacek P., Stwierdzenie nieważności rozkazu personalnego o nawiązaniu, zmianie albo rozwiqzaniu stosunku stużbowego, Państwo i Prawo 2018, z. 8.

24 „Policjantowi przywróconemu do służby przysługuje droga sądowa do dochodzenia roszczenia o utracone korzyści w postaci różnicy pomiędzy uposażeniem, które otrzymałby, gdyby pełnił służbę a świadczeniem za okres pozostawania poza służbą, wypłaconym na podstawie art. 42 ust. 5 ustawy z dnia 6 kwietnia 1990 r. o Policji (t.j. Dz. U. z 2011 r. Nr 287, poz. 1687) [...] Przenosząc te ogólne uwagi na grunt rozpoznawanej sprawy należy stwierdzić, że żądanie powoda jest deliktowym roszczeniem odszkodowawczym, spełniającym wymagania roszczenia procesowego, co kwalifikuje je do rozpoznania na drodze sądowej. Podstawą roszczenia nie jest bowiem żądanie zwiększenia świadczenia administracyjnoprawnego przewidzianego w art. 42 ust. 5 ustawy o Policji, lecz roszczenie cywilne o odszkodowanie w postaci utraconych korzyści z tytułu różnicy pomiędzy uposażeniem, które przysługiwałoby mu, gdyby pełnił służbę a świadczeniem wypłaconym za okres pozostawania poza tą służbą" - uchwała SN - Izba Cywilna z dnia 3 grudnia 2014 r., III CZP 91/14, Legalis nr 1163200. Przeciwnie w wyroku SA w Szczecinie - I Wydział Cywilny z dnia 27 marca 2019 r., I ACa 520/18: „art. 42 ust. 5 ustawy o Policji stanowi przewidziany $\mathrm{w}$ art. $361 \S 2$ k.c. ustawowy wyjątek od zasady pełnej kompensaty w zakresie świadczeń przysługujących przywróconemu do służby policjantowi za czas pozostawania poza tą służbą [...]”. 
Hanausek T., Ustawa o Policji. Komentarz, Kraków 1996.

Hanausek T. i in., Prawo Policyjne. Komentarz, t. 1, red. S. Sagan, Katowice 1992.

Kacprzak J., Stosunki służbowe w formacjach zmilitaryzowanych - charakter prawny, ochrona sądowa, Przegląd Policyjny 1994, nr 1 (33).

Kotowski W., Ustawa o Policji. Komentarz, Warszawa 2008.

Kuczyński T., Stosunki służbowe służb zmilitaryzowanych (mundurowych), w: System Prawa Administracyjnego, t. 11. Stosunek stużbowy, red. R. Hauser, Z. Niewiadomski, A. Wróbel, Warszawa 2011.

Kuczyński T., Wybrane problemy orzecznictwa sądowoadministracyjnego $w$ sprawach $z z a-$ kresu stosunków służbowych, Zeszyty Naukowe Sądownictwa Administracyjnego 2010, nr 5-6 (32-33).

Leksykon policyjny, red. W. Pływaczewski, G. Kędzierska, Szczytno 2001.

Liwo M., Status stużb mundurowych i funkcjonariuszy w nich zatrudnionych, Warszawa 2013. Maciejko W., Osobowe prawo administracyjne, Warszawa 2008.

Maciejko W., Korcz-Maciejko A., Postępowanie w sprawach osobowych w Policji, Wrocław 2010.

Maciejko W., Rojewski M., Suławko-Karetko A., Prawo administracyjne. Zarys wykładu części szczególnej, Warszawa 2011.

Nowikowska M., Uwagi do art. 42, w: Ustawa o Policji. Komentarz, red. K. Chałubińska-Jentkiewicz, J. Kurek, Warszawa 2020 [wyd. el. Legalis].

Opaliński B., Rogalski M., Szustakiewicz P., Uwagi do art. 42, w: Ustawa o Policji. Komentarz, wyd. 1, Warszawa 2015 [wyd. el. Legalis].

Paśnik J., Prawo dyscyplinarne w Polsce, Warszawa 2000.

Szankin T., Stużba w Policji, w: Prawo policyjne, red. M. Czuryk i in., Warszawa 2014.

Szustakiewicz P., Istota stosunku służbowego, w: Stosunek stużbowy w formacjach mundurowych, red. W. Maciejko, P. Szustakiewicz, Warszawa 2016 [wyd. el. Legalis].

Ura E., Ura E., Prawo administracyjne, Warszawa 2004.

Wieczorek M., Charakter prawny stosunków służbowych funkcjonariuszy służb mundurowych, Toruń 2017.

Zieliński T., Stosunek prawa pracy do prawa administracyjnego, Warszawa 1977.

Zorska M., Komentarze do ustaw z 31 stycznia 1950 r. o stosunku służbowym funkcjonariuszów Milicji Obywatelskiej i z 31 stycznia 1959 r. o zaopatrzeniu emerytalnym funkcjonariuszów Milicji Obywatelskiej i ich rodzin, Warszawa 1960. 